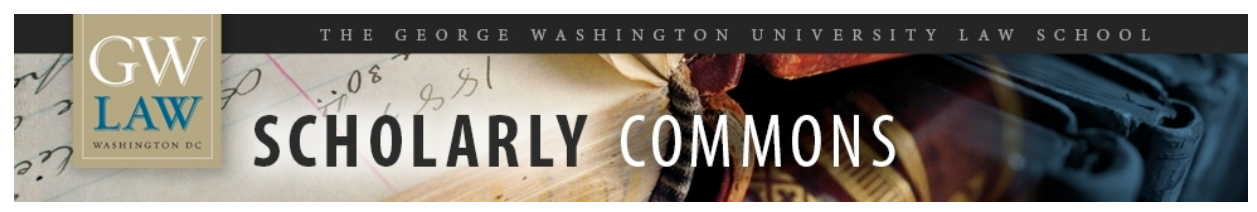

\title{
Prudence in International Strategy: From Lawyerly to Post- Lawyerly
}

Jeremiah S. Pam

The George Washington University Law School

Follow this and additional works at: https://scholarship.law.gwu.edu/faculty_publications

Part of the Law Commons

\section{Recommended Citation}

am, Jeremiah S, Prudence in International Strategy: From Lawyerly to Post-Lawyerly (2017). GWU Law School Public Law Research Paper No. 2017-64; GWU Legal Studies Research Paper No. 2017-64. Available at SSRN: http://ssrn.com/abstract $=3036566$

This Article is brought to you for free and open access by the Faculty Scholarship at Scholarly Commons. It has been accepted for inclusion in GW Law Faculty Publications \& Other Works by an authorized administrator of Scholarly Commons. For more information, please contact spagel@law.gwu.edu. 


\title{
Prudence in International Strategy: From 'Lawyerly' to 'Post-Lawyerly'
}

\author{
JEREMIAH S. PAM ${ }^{*}$
}

TABLE OF CONTENTS

INTRODUCTION

I. Three Personal but Possibly Illustrative Data Points ABout

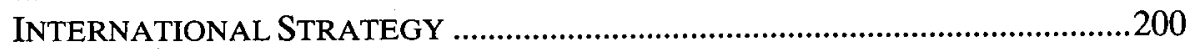

II. The Rise of LAWYerly PrudenCE in INTERnational Strategy .........202

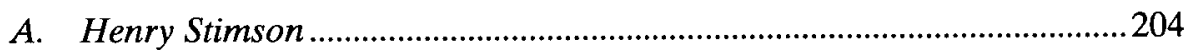

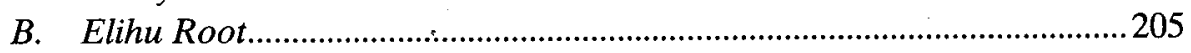

C. John J. McCloy.................................................................................209

D. An Underappreciated Key to the New York Lawyer-Statesman Tradition: Living in Uniquely "Interesting Times"................................212

III. THE FALl OF LAWYERLy PRUDENCE IN INTERNATIONAL STRATEGY .........213

IV. THE FUtURE of PRUdENCE IN INTERNATIONAL StRATEGy: From LAWYERLY TO POST-LAWYERLY .....................................................216

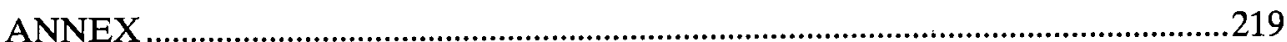

\section{INTRODUCTION}

In considering this symposium's subject of how the international community should respond to the challenge of ISIS, I suspect we can agree that it is imperative to be informed by the recent experiences with interventions in Iraq and Afghanistan. Of

* Research Scholar, Arnold A. Saltzman Institute of War and Peace Studies, Columbia University School of International and Public Affairs. In addition to the organizers of and participants in this Symposium, I am grateful to friends and colleagues for helpful comments during discussions of related subjects over the last four years at Columbia's Law School and Saltzman Institute, Cleary Gottlieb Steen \& Hamilton in New York, and MIT's Sloan School of Management and Security Studies Program, as well as in countless searching and fruitful exchanges with David Wolitz, Dorothy Pam and Robert Pam. All errors remain my own. 
course, the difficult question is how those experiences should inform us. Given my own time in Iraq and Afghanistan, ${ }^{1}$ it is perhaps not surprising that I have a few observations from those interventions that strike me as potentially relevant, to which I will turn very briefly in a moment.

But as I've already written elsewhere about some of these, ${ }^{2}$ what really interests me in the context of this symposium is what might be called the meta-question of how, in general, we should learn from and integrate past experience in thinking about how best to respond to pressing present-day international challenges such as ISIS-and to questions of international strategy defined more broadly - while at the same time giving due consideration to the likely future consequences of such decisions.

Put simply, this is the question of prudence. ${ }^{3}$ While prudence has something of an archaic ring to it today and is not used as often as it once was-with the important but technical exception of the bank regulatory context ${ }^{4}-I$ think its essence is both simple and of continuing relevance. My favorite depiction of what prudence entails can be seen in a wonderful 16th century painting by the Italian Renaissance master Titian, which hangs in the National Gallery in London. ${ }^{s}$ As described by the art historian Erwin Panofsky, the painting shows "the countenance of a middle-aged man

1. From 2006-2007, I worked for the Treasury Department at the U.S. Embassy in Baghdad as the Financial Attaché for Iraq, and from 2010-2012 I worked for the State Department at the U.S. Embassy in Kabul as the Governance Policy Chief.

2. See generally Jeremiah S. PAM, THE TREASURY APPROACH to STATE-BuILding AND INSTITUTION-STRENGTHENING ASSISTANCE: EXPERIENCE IN IRAQ AND BROADER IMPLICATIONS (2008) [hereinafter THE TREASURY APPROACH]; Jeremiah S. Pam, The Paradox of Complexity: Embracing Its Contribution to Situational Understanding, Resisting Its Temptation in Strategy and Operational Plans, in COMPLEX OPERATIONS: NATO AT WAR AND ON THE MARGINS OF WAR 26 (Christopher M. Schnaubelt ed., 2010) [hereinafter The Paradox of Complexity]; Jeremiah S. Pam, The Rise and Fall of Afghan "Subnational" Governance in General: And the Belated Recognition of the Importance of Provincial Governance and Finance in Particular (Saltzman, Working Paper No. 25, 2015), http:/www.siwps.org/wpcontent/uploads/2015/08/Working-Paper-25-Pam.pdf [https://perma.ccl/F6MM-Y6H6] [hereinafter The Rise and Fall].

3. While the celebration of prudence as an important virtue dates to classical antiquity-notably in Aristotle's conception of phronesis (most commonly translated as prudence or practical wisdom) in the Nichomachean Ethics-my own interest in prudence (and its relationship to law:and lawyers) was inspired more recently by Anthony T. Kronman, Alexander Bickel's Philosophy of Prudence, 94 Y.ALE L.J. 1567 (1985) [hereinafter Kronman, Alexander Bickel's Philosophy of Prudence]. For Kronman's development of related themes, see also Anthony T. Kronman, Practical Wisdom and:Professional Character, 4 SOC. PHIL. \& POL'Y 203 (1986); Anthony T. Kronman Living in the Law, 54 U. CHI. L. REV. 835 (1987); ANTHONY T. KRONMAN, THE LOST LAWYER: . FAILING IdEALS OF THE LEGAL PROFESSION (1993).

4. Traditionally, "prudential" regulation has been regulation focused on the safety and soundness of individual financial institutions. Dennis Lockhart, President \& CEO, Fed. Res. Bank of Atlanta, Georgia Law Review Symposium: Thoughts on Prudential Regulation of Financial Firms (Mar. 20, 2015). More recently, and particularly since the financial crisis of 2008 , financial supervisory and regulatory efforts have also been focused on protecting the financial system's ability to deliver vital services to the general economy. Id. Regulation of this sort is referred to as "macroprudential" regulation. Id. Regulation of the older sort targeted at individual financial institutions now referred to as "microprudential." JACEK OSIŃSKI ET AL., MACROPRUDENTIAL AND MICROPRUDENTIAL POLICIES: TOWARD COHABITATION 6 (2013).

5. Titian \& Workshop, An Allegory of Prudence (1565), https:/www.nationalgallery.org.uk/paintings/ titian-and-workshop-an-allegory-of-prudence [https//perma.cc/TLZ2-RL2P]. I first encountered the painting as the cover illustration of John Dunn's collection of essays, Interpreting Political Responsibility. For his discussion of prudence that was an early influence on my thinking, see generally JOHN DUNN, Reconceiving the Content and Character of Modern Political Community, in INTERPRETING POLITICAL RESPONSIBILITY: ESSAYS 1981-1989 193, 193 (1990). 
in full face, the profile to left of an old man, and the profile to right of a youth." Above each of the conjoined partial portraits there is a corresponding inscription in Latin, which translated reads: "[Learning] from yesterday, today acts prudently, lest by his action he spoil tomorrow." The title of the painting is "An Allegory of Prudence.",

This brief Article makes (or at least gestures toward) three points. First, although the general quality of prudence has long been loosely associated with lawyers, ${ }^{9}$ for a discrete period of time in American history (roughly the first two-thirds of the 20th century), one of the most distinctive contributions of a certain type of lawyer - which I will refer to in shorthand as the "New York lawyer-statesman" for historical reasons that will shortly become clear - was the application of prudence not to the practice of law as such, but to the broader domain of U.S. international strategy and policy. Accordingly, the historical part of this Article focuses not on the narrow lawyer's question of "what was understood as "lawful," but rather on what was distinctively "lawyerly" in these lawyer-statesmen's contributions to international strategy - what I call the quality of "lawyerly prudence."

Second, the circumstances that shaped, allowed, and even encouraged such contributions to international strategy by these lawyers had largely run their course by the last third of the 20th century. While other types of prominent lawyers have remained important in public and private affairs - for example, the "Washington lawyer," or the "lawyer's lawyer" found in many cities ${ }^{11}$ - the specific phenomenon of New York lawyer-statesmen contributing their lawyerly prudence to international strategy more or less ended as a distinctive, socially-reproducing tradition during this time. However we feel about this tradition, my argument goes, that ship has sailed.

Third, international strategy nonetheless remains as much in need of prudence now as ever before ${ }^{12}$-arguably more so because of the absence from the scene for the last couple of generations of the lawyerly prudent type. But because New York lawyers can no longer serve as the primary exemplars of lawyerly prudence in this context, we must unpack the elements of the old lawyerly prudence and encourage their self-conscious adoption by a broader group of citizen-statespeople, who have accumulated the kind of direct and relevant experience with what does and does not work in international strategy that is necessary (but not sufficient) to develop and exercise prudence of the old lawyerly kind, even though many or most of such people will not be lawyers.

6. Erwin Panofsky \& Fritz Saxl, A Late Antique Religious Symbol in Works by Holbein and Titian, 49 BURLINGTON MAG. FOR CONNOISSEURS 177, 177 (1926). See also ERWIN PANOFSKY, Titian's Allegory of Prudence: $A$ Postscript, in MEANING IN THE VISUAL ARTS 146 (1955).

7. After 3 Months and 244 Donations, Frame Appeal Hits Its Target, NAT'L GALLERY (Feb. 2015), https:/www.nationalgallery.org.uk/about-us/press-and-media/press-releases/after-3-months-and-244donations-frame-appeal-hits-its-target [https://perma.cc/D3QC-B8v6] (alteration in original) (internal quotation marks omitted).

8. Titian \& Workshop, supra note 5 .

9. See, e.g., Kronman, Alexander Bickel's Philosophy of Prudence, supra note 3, at 1573 ("[P]rudence-'good practical wisdom'-is and will continue to be the lawyer's distinctive virtue ....").

10. Edward O. Laumann et al., Washington Lawyers and Others: The Structure of Washington Representation, 37 STAN. L. REV. 465, 465-66 (1985).

11. See generally WILliam H. HARBAUGH, LAWYER'S LAWYER: THE LIFE OF JOHN W. DAVIS (1973).

12. See generally. MiChaEl MANDELBAUM, MisSion FAILURE: AMERICAN AND THE WORLD IN THE POST-COLD WAR ERA (2016). 
In short, this Article establishes the need for, and preliminarily describes, a new kind of "post-lawyerly" prudence in international strategy. Fortunately, the international events of the last 15 or so years have left us with a significant pool of people with experiences that make them potential candidates to exercise this postlawyerly prudence.

\section{Three Personal but Possibly Illustrative Data POINTS ABOUT INTERNATIONAL STRATEGY}

Since one of the subjects of this symposium is the future of the West's response to ISIS, I will begin with the briefest possible account of three observations from my own experience related to Iraq and Afghanistan. My intention here is not to shift the focus from today and ISIS to the past and other conflicts, but simply to provide illustrative examples of the kind of experience that the concept of prudence demands that we consciously integrate, along with future considerations, in deciding how to act today in response to relevant major international strategic challenges-three data points, if you will. In the interest of time, I will simply set out my three observations.

From 2004 to 2005, while a lawyer in private practice with an international firm in New York, I helped advise the government of Iraq on the restructuring of Iraq's sovereign debt. This resulted in an international agreement to cancel 80 percent of the country's Saddam Hussein-era debt, ultimately saving Iraq approximately $\$ 100$ billion. $^{14}$ The debt restructuring was achieved, first, through international negotiations with country creditors, then through international negotiations with private creditors (and then again through more international negotiations with other country creditors). By most accounts, the debt deal was a rare success of the Iraq effort. ${ }^{15}$ However, it is important to note it was carried out largely outside Iraq. Apart from government decisions made in Baghdad at pivotal junctures, much of the work involved took place in locations like Paris, London, Dubai, and Amman, rather than on the ground in Iraq. ${ }^{16}$

13. Note that the term "post-lawyerly" is intended to capture the idea of the specified "lawyerly" qualities applying to a broader population, rather than any transcendence of, let alone opposition to, the qualities themselves. See infra, Section IV (describing the need for post-lawyerly prudence).

14. See Roula Khalaf et al., Iraq Debt Agreement Ends Stand-off, FIN. TIMES (Nov. 22, 2004, 2:00 AM), http://www.ft.com/cms/s/0/a0174c38-3c2a-11d9-8b17-00000e2511c8.html [https://perma.cc/6JG9-RH6R] (discussing the Paris Club's decision to cancel up to $80 \%$ of Iraqi debt); Craig S. Smith, Major Creditors in Accord to Waive $80 \%$ of Iraq Debt, N.Y. TIMES (Nov. 22, 2004), http://www.nytimes.com/2004/11/22/world/ middleeast/major-creditors-in-accord-to-waive-80-of-iraq-debt.html] [https://perma.cc/3GD6-7QZ3] (describing the effect of the Paris Club's decision on other nations owning Iraqi debt).

15. See Joanna Chung \& Stephen Fidler, Restructuring Under Fire: Why Iraqi Debt Is No Longer a Write-Off, FIN. TIMES (July 17, 2006), http://www.ft.com/cms/s/0/dc70f4f0-1530-11db-b391-0000779e 2340.html?ft_site=falcon\&desktop=true\#axzz4QlwmoKPm [https://perma.cc/D2WJ-9838] ("Even though incomplete, this effort to remove an obstacle to Iraq's economic recovery has been one of the few successful projects undertaken in post-Saddam Iraq.").

16. See Hadi Nicholas Deeb, Project 688: The Restructuring of Iraq's Saddam-Era Debt, RESTRUCTURING NEWSLETTER (Cleary Gottlieb Steen \& Hamilton, New York, N.Y.), Winter 2007, at 3, 6, https:/www.clearygottlieb.com/ /media/cgsh/files/publication-pdfs/cleary-gottlieb-restructuringnewsletter-winter-2007.pdf [https://perma.cc/n5t5-vb87] (describing the various international actors involved in the restructuring process); YVONNE WONG, SOVEREIGN FINANCE AND THE POVERTY OF NATIONS: ODIOUS DEBT IN INTERNATIONAL LAW 54 n.50 (2012) (explaining that the Iraqi Debt Reconciliation Office was set up in Amman, Jordan). 
Not long after, while working for the U.S. Treasury Department as the Financial Attaché for Iraq at the U.S. Embassy in Baghdad from 2006 to 2007, I worked with others to shift Iraqi and Coalition attention away from spending U.S. money through U.S. parallel structures and towards Iraq spending Iraq's money through Iraqi institutions and processes. ${ }^{17}$ This could only be considered a success in that it involved us walking back an approach that was clearly unsustainable in the long term. ${ }^{18}$ However, as the current situation in Iraq underscores, it did not sufficiently strengthen Iraqi governance for Iraq to fully function as an effective state. ${ }^{19}$

Third and finally, from 2010 to 2012, while working for the U.S. State Department as Embassy Kabul's Governance Policy Chief, I worked with others to shift Afghan and international governance efforts from a scattershot approach pursuing a wide variety of governance objectives at many levels of governance-from tens of thousands of villages to hundreds of districts to 34 provinces - to a more focused approach centered around strengthening the budgetary-governance interface between Afghanistan's central ministries and their provincial institutions. ${ }^{20}$ Again, this could only be considered a success in that it walked back international governance objectives that could not be achieved or sustained even at the height of the surge ${ }^{21}$ and certainly could not be sustained after the drawdown. ${ }^{22}$ And here too, it may have been a case of "too little, too late," as it currently appears that Afghan governance has not been sufficiently strengthened for Afghanistan to fully function as an effective state yet either. $^{23}$

With those contemporary points of reference in mind, let me now take a step back in history, to the early and mid-20th century.

17. See JAmes D. SAVAgE, Reconstructing IRAQ's Budgetary INSTITUTIONS: COALITION STATE BUILDING AFTER SADDAM 202-04 (2013); OFFICE OF THE SPECIAL INSPECTOR GENERALFOR IRAQ RECONSTRUCTION, HARD LESSONS: THE IRAQ RECONSTRUCTION EXPERIENCE 267-68 (2009) [hereinafter HARD LESSONS] ("Improving the ability of the Iraqi government to spend its own revenue became the keystone in a new arc of capacity-development activities. It was all part of a shift in the reconstruction program to supporting Iraqi priorities with Iraqi resources."); see also The Paradox of Complexity, supra note 2, at 41 (describing the value of indirect approaches by international actors in working with local parties). See generally THE TREASURY APPROACH, supra note 2 (describing the need for local institution-oriented work in Iraq).

18. HARD LESSONS, supra note 17, at 298 ("The new standard, Meese explained, was 'if it can't be done by the Iraqis, we probably shouldn't do it.' 'What is better is a project that takes 60 days instead of 30 daysbut is done by the Iraqi manager and is sustainable by the Iraqis [and] that their operations can support."').

19. See, e.g., Tim Arango, With Iraq Mired in Turmoil, Some Call for Partitioning the Country, N.Y. TIMES (Apr. 28, 2016), http://www.nytimes.com/2016/04/29/world/middleeast/with-iraq-mired-in-turmoilsome-call-for-partitioning-the-country.html [https://perma.cc/AR82-S4QS] (describing the lack of adequate leadership in the Iraqi government).

20. See Frances Z. Brown, U.S. InSt. of Peace, The U.S. Surge and Afghan Local GOVERNANCE: LESSONS FOR TRANSITION 316 (2012), http:/www.usip.org/sites/default/files/resources/ SR316.pdf [https://perma.cc/9LP6-73EH] (describing the shortcomings of the U.S. effort to transform local governance); The Rise and Fall, supra note 2 (describing the shift from a scattershot approach to a more center-province and budget-focused approach in governance).

21. The Rise and Fall, supra note 2, at 28.

22. Id. at 35 .

23. See, e.g., Philip Reeves, Why Afghanistan Is Once Again on the Brink, NAT'L PuB. Radio (May 5, 2016, 9:38 AM), http:/www.npr.org/sections/parallels/2016/05/05/475928020/why-afghanistan-is-once-againon-the-brink [https://perma.cc/7KHF-YDBX]; Mujib Mashal, Afghanistan Is in Chaos. Is That What Hamid Karzai Wants?, N.Y. TIMES (Aug. 5, 2016), http://www.nytimes.com/2016/08/06/world/asia/afghanistanhamid-karzai.html [https://perma.cc/y87N-2ZVP]. 


\section{THE RISE OF LAWYERLY PRUDENCE IN INTERNATIONAL STRATEGY}

In some respects, this is a story that has been well told elsewhere, perhaps most famously in Walter Isaacson's and Evan Thomas's book The Wise Men. ${ }^{24}$ Pictured on the cover of the book are Robert Lovett, John McCloy, Averell Harriman, Charles Bohlen, George Kennan, and Dean Acheson: Two financiers (Lovett and Harriman), two professional diplomats (Bohlen and Kennan), and two lawyers (McCloy and Acheson).$^{25}$ But the book's preface frames all these figures in the context of a tradition originating with McCloy and Lovett's mentor, New York lawyer Henry Stimson, and with Stimson's mentor, New York lawyer Elihu Root, Sr. ${ }^{26}$ In 1899, President McKinley famously called Root to leave his practice as a very successful corporate lawyer in New York, where he specialized in matters like railroad reorganizations, in order to come down to Washington and serve as McKinley's Secretary of War following the conclusion of the Spanish-American War and America's acquisition of the territories of Puerto Rico, Cuba, and the Philippines. ${ }^{27}$

But while the "wise men" story is well known, ${ }^{28}$ two things about it have attracted less attention. First, why were so many lawyers playing prominent roles in what were clearly policy and strategy decisions? And second, what is the significance of all of the wise men except Acheson having been lifelong New Yorkers (when not serving in government) rather than Washington creatures?

There are some obvious historical factors that must be mentioned: Elite lawyers possessed a disproportionately large share of social and professional capital at the

24. See generally WALTER ISAACSON \& EVAN THOMAS, THE WISE MEN: SIX FRIENDS AND THE WORLD THEY MADE (1986).

25. Id. at $17-25$.

26. Id. at $28-29,180$.

27. See EliHu Root, AdDRESSES ON GOVERnMENT AND CITIZENSHIP 503-04 (Robert Bacon \& James Brown Scott eds., 1916). Root gave his own account of receiving the offer from President McKinley in an address to the New York County Lawyers' Association on March 13, 1915. Id. Here is the key passage:

Sixteen years ago, in the month of July [1899], .. . I was called to the telephone and told by one speaking for President McKinley, 'The President directs me to say to you that he wishes you to take the position of Secretary of War.' I answered 'Thank the President for me, but say that it is quite absurd, I know nothing about war. I know nothing about the army.' I was told to hold the wire and in a moment there came back the reply, 'President McKinley directs me to say that he is not looking for any one who knows anything about war or for any one who knows anything about the army; he has got to have a lawyer to direct the government of these Spanish islands, and you are the lawyer he wants.' Of course I had then, on the instant, to determine what kind of lawyer I wished to be, and there was but one answer to make, and so I went to perform a lawyer's duty upon the call of the greatest of all our clients, the Government of our country.

Id.

28. See, e.g., Bryce Nelson, The Wise Men: Six Friends and the World They Made, L.A. TIMES (Nov. 30, 1986), http://articles.latimes.com/1986-11-30/books/bk-106_1_wise-men [https://perma.cc/L7B2-GL7Y] (book review) (calling the book "compulsory reading for anyone wishing to understand modern American foreign policy"). 
time. ${ }^{29}$ At the time, New York was by far the most international city in the U.S. ${ }^{30}$ And Washington, D.C. was not very developed prior to the New Deal and World War II. ${ }^{31}$ Each of these historical factors played a role. I argue, however, that there were also at least four other important elements. I will first outline them schematically then elaborate on them by reference to three illustrative New York lawyer-statesmen.

First, sophisticated corporate lawyers had notable experience with complexity in the real world: Large, far-flung undertakings that involved dealing with multiple and competing agendas and interests, such as continental railroad mergers and reorganizations, an experience of significant practical relevance to America's new global role in the 20 th century.

Second and relatedly, corporate lawyers had a heightened awareness of uncertainty inherent in undertakings with many moving parts that interact with each other and frequently produce unintended, emergent effects-perhaps the conditions of international relations par excellence.

Third, well-educated lawyers were better prepared than many of their contemporaries in the policy elite to have some self-conscious appreciation of at least recent history as something that necessarily influences, and constrains the forms of, political change. This is one of the fundamental lessons of common law training: Precedents always have to be considered (even when departing from them).

Fourth, the figures happened to live in an extraordinarily eventful time in which to gather lessons of experience. The demands of the period and the norms of the time conspired such that it was possible for contemporaries to develop a substantial stock of direct experience of strategically consequential events. These days, when we look

29. Using the reflexive sociology method of Pierre Bourdieu and drawing on Lauro Martines' history of lawyers in early modern Europe, Bryant Garth and Yves Dezelay have described a transnational pattern in the 19th and 20th centuries by which various kinds of capital (including familial, economic, learned, cosmopolitan, political, and religious) combined to create national groups of elite lawyers possessing distinctive social capital recognized as valuable in intermediating between private interests and the state. YVES DEZALAY \& BRYANT G. GARTH, ASIAN LEGAL REVIVALS: LAWYERS IN'THE SHADOW OF EMPIRE 22-23, 54 (2010) (providing a general description of this process); see also Yves Dezalay \& Bryant G. Garth, Law, Lawyers, and Empire, in 3 THE CAMBRIDGE HISTORY OF LAW IN AMERICA 718, 718-57 (Michael Grossberg \& Christopher Tomlin eds., 2008) (applying the analytical framework to the elite American lawyers of the 20 th century U.S. foreign policy establishment).

30. See James R. Kurth, Between Europe and America: The New York Foreign Policy Elite, in CAPITAL OF THE AMERICAN CENTURY: THE NATIONAL AND INTERNATIONAL INFLUENCE OF NEW YORK CITY 71 , 73 (Martin Shefter ed., 1993) (discussing how New York was thought of almost as part of Europe due to its commercial sophistication and international ties).

31. At the turn of the 20th century, criticism of Washington, D.C.'s urban and aesthetic shortcomings in 1901 prompted the U.S. Senate to appoint the Senate Park Commission, chaired by Senator James McMillan, to make recommendations on a plan for improvements. Jon A. Peterson, The Senate Park Commission Plan for Washington, D.C.: A New Vision for the Capital and the Nation, in DESIGNING THE Nation's Capital: The 1901 Plan for Washington, D.C. 1, 6-9 (Sue Kohler \& Pamela Scott eds., 2006). The resulting 1902 McMillan Plan set out a comprehensive plan for the demolition of slums around the existing federal buildings, the modernization of rail facilities, the development of the Mall and the surrounding monuments and museums, and the clearance of space for future federal office buildings. Id. However, the plan was implemented slowly over the next three decades, with major elements not completed until the 1930s and 1940s during the recovery from the Great Depression and the advent of World War II. Timothy Davis, Beyond the Mall: The Senate Park Commission's Plans for Washington's Park System, in Designing the Nation's Capital: The 1901 Plan for Washington, D.C. 137, 163 (Sue Kohler \& Pamela Scott eds., 2006). 
back historically at pivotal periods of the 20th century, we often focus most on World War II, the creation of the post-war order and institutions, and the so-called "Greatest Generation" involved in these accomplishments. But the key factor that gave rise to the tradition of lawyers acquiring and exercising prudence regarding international strategy actually started earlier, and lay with the contingent historical fact that key individual figures were the right age to be active during the two world wars (as well as during the profound economic challenges of the interwar period).

These elements can be illustrated by just the most skeletal account of three central figures: Henry Stimson (1867-1950), Elihu Root, Jr. (1881-1967), and John J. McCloy (1895-1989).

\section{A. Henry Stimson}

Born in New York City, Henry Stimson was educated at Phillips Academy in Andover, Massachusetts, Yale College (class of 1888), and Harvard Law School (class of 1890). ${ }^{32}$ In 1891, he joined the prominent Wall Street legal practice of Elihu Root, Sr. and Samuel Clarke. ${ }^{33}$ Over the course of the previous two decades, Root had earned a reputation as a brilliant and effective lawyer for some of the period's largest corporate interests, including the Havemeyer sugar refining companies (known as the Sugar Trust) and the many railway-related matters (including mergers, acquisitions, and reorganizations) of William C. Whitney, Jay Gould, and E.H. Harriman. ${ }^{34}$ The Root Clarke firm was among the elite group of New York law firms that, while still intimate by comparison to what they would become in the late 20th century, were developing the sophistication to focus on national and, increasingly, international business. ${ }^{35}$ One of Root Sr.'s biographers described his defining characteristic as having "an extraordinary talent for finding workable solutions to technical and complex problems." ${ }^{36}$ And yet, when Root, Sr. accepted President McKinley's appointment as Secretary of War in 1899, he turned over primary responsibility for this sophisticated practice on behalf of extremely sophisticated business clients to Stimson and another young lawyer who had joined the firm, Bronson Winthrop ${ }^{37}$ (in 1901 , the firm would become Winthrop \& Stimson). ${ }^{38}$ Stimson's mastery of a legal practice requiring an understanding not only of law but of some of the largest and most complicated business arrangements of the day (some of which, like the Sugar Trust, he subsequently encountered from the opposite side of the table when enforcing antitrust laws while serving as the U.S. Attorney for the Southern District of New York from

32. See Henry L. Stimson \& McGeorge Bundy, On Active SERvice in PEACE AND WaR xiii-xv (1947) (discussing Stimson's education).

33. GODFREy HodgSON, THE COLONEL: THE LIFE AND WARS OF HENRY STIMSON 1867-1950, at 48 (1990); STIMSON \& MCGEORGE, supra note 32, at xviii.

34. David Goddard, Colonizing Southampton: THE Transformation OF a Long IsLAND COMMUNITY, 1870-1900 64 (2011).

35. See HODGSON, supra note 33, at 56 (stating that firms such as Root \& Clark were turning to more international affairs).

36. RICHARD W. LEOPOLD, ELIHU ROOT AND THE CONSERVATIVE TRADITION 6 (1954).

37. Hodgson, supra note 33, at 57; see Elting E. MORISON, TURMOIL AND TRADITION: A STUDY OF THE LIFE AND TIMES OF HENRY L. STIMSON 71 (1960) (stating that after the appointment of Root to Secretary of War the "steadying influence of the senior partner was withdrawn ... the two young men ... set out to defend the business they had inherited").

38. HODGSON, supra note 33 , at 57. 
1906-1909) ${ }^{39}$ imbued in him an appreciation of both the complexity of national- and international-scale undertakings, and the inevitability of some irreducible uncertainty as to the outcomes of such things. ${ }^{40}$ This appreciation would serve him well in both his remaining legal career and in his subsequent public offices, which included his service as Secretary of War under President Taft from 1911-1913, as Governor-General of the Philippines under President Coolidge from 1927-1929, as Secretary of State under President Hoover from 1929-1933, and again as Secretary of War under Presidents Franklin Roosevelt and Harry Truman from 1940-1945. Merely listing these offices conveys both the depth and breadth of Stimson's experience in international affairs. ${ }^{41}$

In April 1917, when America entered World War I, Stimson was not in public office but once again a private lawyer and citizen, aged $49 .{ }^{42}$ Once war was declared, however, one of his biographers recounts:

$[\mathrm{H}] \mathrm{e}$ threw himself into the not-so-easy task of getting into uniform, and not just into uniform, but into active service abroad. For this purpose he pulled strings shamelessly.... He got his name onto the list of officers for the artillery-his chosen branch of the service-only to have it removed personally by President Wilson's Secretary of War, Newton D. Baker.... [But] as Stimson left Baker's office after a somewhat abrasive encounter, the door to the office of the chief of staff, Major General Hugh Scott, was open.... Through his intervention, Stimson found himself, on the verge of his fiftieth birthday, training... preparatory to going to France. ... In July his battalion led the Seventy-seventh Regiment into the line with Colonel Stimson in temporary command. ... His unit was only in the line for those three weeks, but in that time, he reckoned, "he saw enough of war and danger to be able to feel certain that he was a good soldier; this knowledge was important to him." 43

In his memoir, Stimson said that of his motivations,

[T] he basic one was that, after preaching preparedness for years and war for months, he could not in conscience remain a civilian. Though in some ways it might be quixotic for a man nearly fifty to become a soldier, it was the only way in which Stimson could feel comfortable in his mind. ${ }^{44}$

\section{B. Elihu Root, Jr.}

While Stimson's mentor, Elihu Root, Sr., was too old to be involved in both wars, Root's son, Elihu Root, Jr. (born in 1881), 15 years younger than Stimson and cofounder with Grenville Clark of his own New York law firm, Root Clark, ${ }^{45}$ served full-

39. Id. at $58-70$.

40. Id.

41. For Stimson's second tenure as Secretary of War during WWII, see infra note 99 and accompanying text.

42. HODGSON, supra note 33 , at $83-84$.

43. Id. at $83-85$

44. Id. at 85 .

45. See Leo GotTlieb, CleARy, Gottlieb, SteEn \& HAMilton: THE First ThirTy YeARS 47-53 (1983) (discussing the history of the Root Clark firm). 
time in the WWI effort when he was already a 35 -year old established lawyer, ${ }^{46}$ and during WWII, in his 60s, played an important role advising the Army Air Force on strategy for the European offensive. ${ }^{47}$ Two short anecdotes from Elihu Root, Jr.'s life illustrate the experiences that both gave rise to and embodied his lawyerly prudence in international strategy.

The first occurred shortly after the Cunard ocean liner RMS Lusitania was torpedoed and sunk by a German U-boat off the coast of Ireland, killing some 1,200 passengers, including 124 Americans. ${ }^{48}$. When the news made it to New York, on Sunday, May 9, the 34 year-old Root and his partner Clark were scheduled to play golf together in Westchester, New York. ${ }^{49}$ But rather than play golf, the two partners ended up engaged in a long and intense conversation about what the tragedy meant for the United States's future role in the war raging in Europe, which led them both to the conclusion that "inaction was intolerable." 50 With Clark taking the lead, Root and a dozen other lawyers and professional men gathered the next evening in Root Clark's downtown office to prepare a public statement. ${ }^{51}$ The following day a larger group of such prominent professional men met over lunch at the Harvard Club to form a formal committee pledging support for a more internationally engaged role for the country. ${ }^{52}$ Finally, following consultations with the well-known Army General Leonard Wood, the committee proposed that a military training camp for college students scheduled to take place that summer in Plattsburg, upstate New York, be adapted to train older professional men such as lawyers and bankers between the ages of 30 and 40 (the "Business Men's Camp"), to serve as the nucleus of an officer corps in the event the United States required a large-scale popular mobilization to enter World War I. ${ }^{53}$ In due course, the proposal of Clark, Root, and their like-minded New York professional (and social) peers was accepted by the government, and the first training camp at Plattsburg took place from August 8 to September 6, 1915. ${ }^{54}$ This novel citizen-soldier initiative (which was repeated in 1916) became known as the Plattsburg Movement and, following the Selective Service Act of 1917, did in fact provide many of the officers mobilized for service in Europe once the U.S. entered the war. ${ }^{55}$ During the war, Clark worked in the office of the Adjutant General, which was responsible for mobilizing the wartime force with the rank of lieutenant colonel. ${ }^{56}$ Root served in the Allied Expeditionary Force as a major in the 304th Infantry ${ }^{57}$ (and with both Root and Clark taken away by the war from their still young law firm, Elihu Root, Sr., having recently completed his term as a U.S. Senator from New York in March 1915, generously

\section{Id. at 47 .}

47. Elihu Root Jr., Lawyer, Is Dead; Statesman's Son a Civic Leader: Arts Patron and Yachtsman Received Truman Medal-Leading La Guardia Backer, N.Y. TIMES, Aug. 28, 1967, at 31 [hereinafter Elihu Root Jr., Lawyer, Is Dead].

48. Gerald T. Dunne, Grenville Clark: Public Citizen 36-37 (1986).

49. Id. at 37 .

50. Id.

51. Id. at $37-40$.

52. Id. at 40 .

53. Id. at 40-45.

54. John Garry Clifford, The Citizen Soldiers: The Plattsburg training Camp MOVEMENT, 1913-1920 54-60 (1972).

55. $I d$.

56. See DUNNE, supra note 48 , at 46.

57. Elihu Root Jr., Lawyer, Is Dead, supra note 47, at 31. 
volunteered to help cover the firm's business in their absence-about which Clark later said, "[t]he truth is that the Senator pretty much set us up in business. His prestige was enormous and his kindness and interest in us beyond measure.").

The second anecdote illustrating Elihu Root, Jr.'s lawyerly prudence in international strategy came more than 25 years later, in the midst of World War II. In late 1942, the highest levels of the U.S. civilian and military war leadership were consumed with intense debates about both the relative priority that should be assigned to the different theaters of the conflict (i.e., Europe vs. the Mediterranean vs. the Pacific) and the relative effectiveness of (and thus the resources that should be devoted to) the different arms of the military (i.e., army, air forces, navy) in prosecuting a campaign in the main theaters. ${ }^{59}$ Perhaps the most pressing question to be resolved was the most effective way to prepare to invade and retake continental Europe. To help answer this question, the most senior leaders of the Army Air Forces (AAF) decided to convene a small, outside group to analyze how a sustained air campaign against strategic targets in western Europe might most effectively degrade the German war effort sufficient to enable a successful ground invasion. ${ }^{60}$ Notwithstanding the existing intelligence and analytical resources already available to the AAF, the leaders were interested in getting a new perspective ${ }^{62}$ and were intrigued by the nascent idea of "operations research," which involved careful analysis of interactions within networks. ${ }^{62}$ They believed both that AAF personnel lacked the background to conduct such analysis and that a certain kind of civilian might be better equipped to do so. ${ }^{63}$ Specifically, the AAF sought "civilians with considerable experience in analyzing large, complex problems." ${ }^{\circ 4}$ Accordingly, the AAF officers charged with setting up this committe $\mathrm{e}^{65}$ ended up assembling a group including a disproportionate number of New York corporate lawyers, and the first person they turned to was none other than Elihu Root, Jr., then 62 years old. ${ }^{66}$ Also invited to join the group, which was to become known as the Committee of Operations Analysts (COA), were: Fowler Hamilton, former Department of Justice antitrust lawyer turned "economic warfare" expert who a few years later would be among the founders of the Root Clark offshoot firm still known today as Cleary, Gottlieb, Steen \& Hamilton; and Major Barton

58. GOTTLIEB, supra note 45 , at 48 .

59. See Robert C. Ehrhart et al., Building an Air Intelligence Organization and the European Theater, in PIERCING THE Fog: INTELligenCE AND ARMY AIR FORCES OPERATIONS IN WORLD WAR II 111, 15052 (John F. Kreis ed., 1996) (detailing President Roosevelt's request of the AAF to garner the best way to retake Europe).

60. See id. at 152 (examining the date when strategic air targets would lead to the deterioration of the German war effort and thus permit a successful invasion of Western Europe).

61. See id. (stating that because the military had come across operations research, a new technique, General Arnold sought to explore it).

62. See id. (discussing the military's recent discovery of operations research).

63. See id. (explaining that military officers lacked the training and the time needed for economic analysis, and therefore the inclusion of civilians, especially prominent civilians, would be better).

64. RonALD SCHAFFER, WINGS OF JUdGMENT: AMERICAN BOMBING IN WORLD WAR II 110 (1985).

65. The principal staff officers involved were Colonel Byron Gates, Director of Management Control at AAF headquarters, and Gates' executive officer, Major Guido Perera, who had been a corporate lawyer in Boston before the war. $I d$.

66. See Ehrhart et al., supra note 59, at 152 (explaining that Gates and Perera reached out to Elihu Root, Jr. to ask for his participation even before receiving Arnold's official directive). 
Leach, a property law expert on leave from the faculty of Harvard Law School. ${ }^{67}$ Rounding out the civilian members of the COA were economics professor Edward Mason from Harvard, military historian Edward Mead Earle of the Institute for Advanced Study in Princeton, and the eminent New York banker Thomas Lamont (then 73), who for some 30 years had been the international face of J.P. Morgan. ${ }^{68}$

The activities, conclusions, and impact of this Committee of Operations Analysts $^{69}$ (which, it must be noted, also included a number of non-lawyer, active duty AAF officers) are for another article. ${ }^{70}$ But one general observation about Elihu Root, Jr.'s work on the COA is relevant to our argument. In his first-hand account of the experience, Major Perera (the Executive Officer) specifically noted Root Jr.'s awareness of the inherent limitations in analysts' ability to fully predict the result of the interactions between Allied forces' successful targeting of one part of a complex system and the Axis forces' reactions to the damage done. ${ }^{71}$

I recall [Mr. Root's] prophetic statement that it was impossible to determine in advance what man's ingenuity might accomplish when faced with desperate necessity. We could never conjure up all of the methods the enemy would devise to repair the damage inflicted on his vital targets, to substitute other products for those being produced there or even to manage to get along without such products. $^{72}$

67. See id. at 153 (explaining who joined the group); see also SCHAFFER, supra 64, at 196 (explaining who joined the group); W. Barton Leach Dies; On Faculty Since 1929, HARVARD CRIMSON (Dec. 17, 1971), http://www.thecrimson.com/article/1971/12/17/w-barton-leach-dies-on-faculty [https://perma.cc/QBE98G7M] (detailing Barton's teaching at Harvard Law School); Walter H. Waggoner, Fowler Hamilton, 73, Is Dead; Directed A.I.D. for Kennedy, N.Y. TIMES (June 9, 1984), http://www.nytimes.com/1984/06/09/ obituaries/fowler-hamilton-73-is-dead-directed-aid-for-kennedy.html [https:/perma.cc/N4KL-DBRB] (detailing Hamilton's career including his time at the DOJ and Cleary Gottlieb).

68. See SCHAFFER, supra note 64, at 110-11 (explaining who joined the group).

69. For the AAF's nearly contemporaneous official account of the two-year history of the COA (which was apparently written by Major Perera), see generally U.S. DEP'T OF THE AIRFORCE, HISTORY OF THE ORGANIZATION AND OPERATIONS OF THE COMMITTEE OF OPERATIONS ANALYSTS (1944).

70. Such an article could also describe the periodic bureaucratic tensions between (1) the COA commissioned by HQ AAF in Washington; (2) the operations analysis section already established within the staff of Eighth Air Force in England, which was led by another Root Clark lawyer, the future Supreme Court Justice John M. Harlan II, and his deputy Leslie Arps, a younger Root Clark lawyer who would in 1948 be one of the founders of the major New York law firm now known as Skadden, Arps, Slate, Meagher \& Flom; and (3) the group of mostly civilian economists assembled by the Office of Strategic Services (the wartime predecessor to the Central Intelligence Agency) as the Enemy Objectives Unit in an annex of the U.S. Embassy in London, which was headed by future MIT economics professor Charles Kindleberger and included, among others, future National Security Advisor to President Lyndon Johnson Walt Rostow, future Deputy National Security Advisor to President Kennedy Carl Kaysen, and future Federal Reserve Bank of New York and U.S. Treasury senior official Robert Roosa. On John Harlan and the Eighth Air Force operations analysis section, see J. Edward Lumbard, John Harlan: In Public Service 1925-1971, 85 HARV. L. REV. 372, 373-74 (1971). On Leslie Arps, see Dennis Hevesi, Leslie H. Arps Dies; A Founding Member of Major Law Firm, N.Y. TIMES (July 16, 1987), https:/www.nytimes.com/1987/07/16/obituaries/leslie-harps-dies-a-founding-member-of-major-law-firm.html [https:/perma.cc/V7AB-VNKA]. On the Enemy Objectives Unit, see W.W. Rostow, Waging Economic Warfare from London: The Enemy Objective Unit, CIA: STUD. INTELLIGENCE (May 8, 2007, 9:01 AM), https:/www.cia.gov/library/center-for-the-study-ofintelligence/kent-csi/vol35no4/html/v35i4a06p_0001.htm [https://perma.cc/ZU4T-27SH]; Interview by Richard D. McKinzie with Charles P. Kindleberger, Chief of German and Austrian Economic Affairs Division, Department of State, in Cambridge, Mass. (July 16, 1973), https:/www.trumanlibrary.org/oralhist/ kindbrgr.htm [https://perma.cc/9RKE-NCD2].

71. 2 GUIDO PERERA, LEAVES FROM MY BOOK OF LIFE 79 (1975).

72. Id. 
Perera also connected this awareness of inherent uncertainty that follows from interactive complexity to Root's humility: "Elihu Root, Jr., was a very modest man but his modesty was in no sense affected; it was securely based on a thorough and penetrating intellect and a flawless character."73

In 1945, Elihu Root, Jr. was awarded the highest civilian decoration, the Medal for Merit, for his work on the Committee of Operational Analysts. ${ }^{74}$ Perera's memoir reproduces a photo of the ceremony showing Root with Fowler Hamilton, Barton Leach and himself (all lawyers), and reprints a letter from Root to him saying "there should have been four medals or none, for if four men ever worked in complete and unstratified equality you and Bart and Fowler and I did during our years on the steering committee of the COA."75

\section{John J. McCloy}

John J. McCloy, the third and youngest of our exemplars of lawyerly prudence, was born in Philadelphia in 1895 to modest but proud circumstances. ${ }^{76}$ Here also we will satisfy ourselves with two anecdotes that illustrate how he acquired and exercised lawyerly prudence in international affairs.

Entering Amherst College in 1912, McCloy completed his junior year in May 1915 and sought out the opportunity to attend the four-week military training camp for college students at Plattsburg referred to earlier. ${ }^{77}$ After completing training, he requested to remain for the "Business Men's Camp" beginning the next week, where he was exposed to many of the elite lawyers and businessmen who had responded to Grenville Clark and Elihu Root's call. ${ }^{78}$ After graduating from Amherst in 1916, he again attended the business men's camp at Plattsburg, where he may have met firsttime attendee Henry Stimson. ${ }^{79}$ In the fall of 1916, McCloy entered Harvard Law School, where he crossed paths with many men already on the fast track to a prominent career in law, including Dean Acheson and Leo Gottlieb, but was himself only a middling student. ${ }^{80}$ Over the course of his first year at the law school, news of the war in Europe became increasingly grave. ${ }^{81}$ By the end of the year, McCloy had decided to attend the Plattsburg camp for the third time in the summer of 1917, with the goal of winning a regular commission as a field artillery officer by the end of the summer. ${ }^{82}$

He succeeded in his goal, and was invited to serve as aide-de-camp to Brigadier General Guy Preston. ${ }^{83}$ General Preston and Lieutenant McCoy shipped out for

73. Id.

74. Id. at 150 .

75. Id. at 151; Lauris Norstad, W. Barton Leach: In His Country's Service, 85 HARV. L. REV. 726, 72628 (1972).

76. KAI BIRD, THE CHAIRMAN: JOHN J. MCCloy \& THE MAKING OF THE AMERICAN ESTABLISHMENT 25 (1992).

77. Id. at 40.

78. Id. at 41 .

79. Id. at $45-46$.

80. Id. at 49 .

81. Id. at 50.

82. BIRD, supra note 76 , at 50 .

83. Id. at 51 . 
France with the $160^{\text {th }}$ Field Artillery Brigade in July $1918 .{ }^{84}$ After seeing a little action before Armistice Day on November 11, 1918, McCloy was transferred to General Pershing's AEF headquarters at Chaumont, where he met many of the great leaders of the Army, ${ }^{85}$ including General John J. Pershing, ${ }^{86}$ George C. Marshall, ${ }^{87}$ and Douglas MacArthur, ${ }^{88}$ as well one of the greatest popular heroes of the war, William "Wild Bill" Donovan. ${ }^{89}$ With most of the mission accomplished, McCloy was soon discharged, and he re-entered Harvard Law School in the fall of 1919 and graduated in $1921 .^{90}$ McCloy's World War I experience thus constituted a precocious first step in what would become his long career of acquiring direct experience in events of great international significance.

McCloy then pursued a career as a corporate lawyer in New York, working first for the well-regarded but somewhat sleepy firm of Cadwalader, Wickersham \& Taft, and then transferring after three years to the city's most advanced law firm, the Cravath firm. ${ }^{91}$ Cravath represented the vanguard of the modern "law factory," where a small number of experienced senior lawyers each trained and put to work groups of junior associates, and transmitted the firm culture of a rigid insistence on excellence. ${ }^{92}$ McCloy went on to practice at Cravath for nearly 20 years, finding both intellectually rewarding legal work and the opportunity to live and travel widely abroad. ${ }^{93} \mathrm{He}$ even occasionally worked on issues with an international and public dimension, as with the extended investigation he conducted into the responsibility for a notorious 1916 explosion of a U.S. arms depot on Black Tom Island in New York Harbor. ${ }^{94}$ In 1934 ,

84. Id. at 52 .

85. Id.

86. Incidentally, Pershing was himself trained as a lawyer at the University of Nebraska Law School when he was assigned to the university as military instructor during the early 1890 s, and at the law school formed a lifelong friendship with Charles Dawes, the prominent international banker who received the Nobel Prize in 1925 for formulating the Dawes Plan to attempt to deal with post-WWI reparations issues and went on to serve as Calvin Coolidge's Vice President. JIM LACEY, PERSHING: A BIOGRAPHY 19 (2008).

87. Marshall went on to serve as Chief of Staff of the Army throughout WWII, then as Secretary of State under President Truman. Forrest C. Pogue, George Catlett Marshall, ENCYCLOPEDIA BRITANNICA, https://www.britannica.com/biography/George-C-Marshall [https://perma.cc/4GY7-YVJX].

88. MacArthur served as Chief of Staff of the Army during the 1930s, commander of allied forces in the Pacific during WWII, military governor of Japan during the post-war occupation, and initial commander of UN forces during the Korean War. D. Clayton James, Douglas MacArthur, ENCYCLOPEDIA BRITANNICA, https://www.britannica.com/biography/Douglas-MacArthur [https://perma.cc/S3MG-F3EP].

89. Donovan, a Columbia Law School graduate who was a prominent lawyer in his hometown of Buffalo, NY, would go on during World War II to found the Office of Strategic Services. BIRD, supra note 76 , at 52 .

90. Id. at 53,56 .

91. Id. at 61 .

92. It is interesting to note, however, that by the time McCloy joined the Cravath firm in 1921, the legendarily hard-driving and rigid founder Paul Cravath, who had served during ex-WWI as an advisor to senior U.S. and international figures and was sometimes called to operate in a quasi-diplomatic capacity, had been changed by his wartime experience. See id. at 63 (stating Cravath's junior partner Swaine wrote that "The Cravath who returned from World War I was a much more human person than the prewar Cravath.... He acquired tolerance. He learned that few men are unfailing in their judgements and he became less sure of his own and less insistent that everything be done his way"); see also Priscilla Roberts, Paul D. Cravath, The First World War, and the Anglophile Internationalist Tradition, 51 AuSTL. J. POL. \& HIST. 194, 199 (2005) (explaining that WWI changed Cravath's view).

93. BIRD, supra note 76, at 61-77.

94. See Michael S. Mayer, Presidential Profiles: The Eisenhower Years 488 (2010) (discussing McCloy's involvement in the Black Tom Island case where his clients were awarded $\$ 50$ million 
new evidence about shadowy sabotage networks during WWI allowed McCloy to successfully re-open and eventually win in 1939 an action for damages against Germany for the destruction caused by the 1916 explosion. ${ }^{95}$ This naturally attracted much public attention in the charged early WWII environment. ${ }^{96}$

Nonetheless, when in 1940 McCloy received a call from Henry Stimson, the recently re-appointed Secretary of War, ${ }^{97}$ requesting that he come to Washington to assist in some War Department matters, McCloy did not hesitate to accept, and shortly thereafter he resigned from his partnership in the Cravath firm and relocated to Washington. ${ }^{98}$

It is futile for this brief Article to try to do justice to McCloy's WWII career as a public servant or to his subsequent intermittent service in important public roles after the war. He was generally recognized as perhaps the most irreplaceable of Secretary Stimson's key advisors during WWII, ${ }^{99}$ he served as the second president of the World Bank from 1947-1949, and he was the first civilian U.S. High Commissioner for

against saboteurs working for the German government).

95. BIRD, supra note 76, at 78-95.

96. Id. at 113 (explaining that in the autumn of 1940 "[t]he newspapers were filled with stories of mysterious munition explosions," reminiscent of the Black Tom Island case).

97. The famous story goes that the origin of Stimson's second appointment as Secretary of War in 1940 (when he was 73) lay with a private conversation in May 1940 between then Supreme Court Justice Felix Frankfurter and his old Harvard Law School classmate and friend Grenville Clark about the need for a "wartime" Secretary of War (to replace Harry Woodring) given the tenor of the news from Europe at the time. DUNNE, supra note 48, at 125-27, 131-32. Clark and Frankfurter drew up separate lists of their top choices for the post, and when Stimson's name appeared on both men's lists, they agreed immediately to promote his candidacy, with Frankfurter passing on the idea to President Roosevelt and Clark laying the groundwork with Stimson. Id. By June 1940, Roosevelt had called Stimson to offer him the position, and Stimson accepted-with the proviso that he would be assisted in the undertaking by an immediate circle of aides including some of the sharpest younger men. Id. These key aides turned out to be New York lawyer and judge Robert Patterson, Boston lawyer Harvey Bundy, New York banker Robert Lovett, and New York lawyer John McCloy. Id.

98. See BIRD, supra note 76, at 121-22 ("On December 18, Stimson went to see FDR and got the president's approval to appoint both McCloy and Lovett as 'Special Assistants to the Secretary of War' at a salary of $\$ 8,000$ each. McCloy had formally terminated his Cravath partnership on December 7, 1940, though he viewed this break as a temporary separation, not a divorce.").

99. In his memoir discussing this period, Stimson observed that:

So varied were [McCloy's] labors and so catholic his interests that they defy summary. For five years McCloy was the man who handled everything that no one else happened to be handling. He became Stimson's principal adviser in the battle for the Lend-Lease Act and it was his skillful preparation that cleared the way for the War Department's successful assumption of the whole military burden of lend-lease procurement. Later he was Stimson's chief adviser on matters connected with international relations and his agent in supervising the great work of military government. He was equally good in a complicated interdepartmental negotiation or in dealing with Congress. His energy was enormous, and his optimism almost unquenchable. He became so knowing in the ways of Washington that Stimson sometimes wondered whether anyone in the administration ever acted without 'having a word with McCloy' ....

Henry L. Stimson \& MCGeorge Bundy, ON Active Service in Peace \& War $342-43$ (1947). Another accomplishment worthy of note was McCloy's supervision of the construction of the new Pentagon building across the Potomac when War Department wartime needs rapidly outstripped the space available to it - an innovative project to design and build the world's most capacious office building in record time (nonetheless the project was known for a time as "McCloy's Folly"). BIRD, supra note 76, at 177. 
Germany from 1949-1952. Exploring these topics, however, must be left to other articles or books. ${ }^{100}$

But among the things that particularly marked McCloy (and Elihu Root, Jr. and Henry Stimson) as exemplary was his (and their) exceptional ability to move from the private practice of law at the highest levels in New York to the public practice of international strategy at the highest levels in Washington and throughout the worldand not just once, but during multiple periods of extraordinary strategic consequence. In other words, McCloy, Root, and Stimson did not just begin as New York lawyers and then get pulled permanently into the Washington policy orbit. Instead, after completing their public service during periods of maximum need, they returned to New York to resume exercising their lawyerly abilities in the distinctive setting of private legal practice - and all three of these figures did this at least twice (and often more than that) as the nation moved from WWI to the interwar period, and then to WWII and the postwar period. By contrast, most of their contemporaries who experienced even some of these momentous events usually left the next crisis to subsequent generations, as they often followed a pattern of either moving permanently from their original professional base to Washington after initially being called to it by a major event like a world war, or performing a finite period of public service and then returning home for good. ${ }^{101}$

\section{An Underappreciated Key to the New York Lawyer-Statesman Tradition: Living in Uniquely "Interesting Times"}

Notwithstanding the inherent drama of even brief accounts of these three exemplary New York lawyer-statesmen, the point most relevant to the argument of this Article is less about what they did than it is about when and how they did it. It is by no means a coincidence that I selected three New York lawyer-statesmen who each served in various capacities (reflecting in part their different ages during the key years) in both World War I and World War II. One of the reasons Stimson, Root, Jr., and McCloy were able to acquire the experience they did is almost shockingly straightforward: They simply were born in just the right narrow window of time-the less than 30 years between 1867 and $1895 .^{103}$ Aside from their individual qualities, this fact was necessary for them to see more, do more, and learn more through direct experience about what does and does not work in truly consequential international strategy than lawyer-statesmen before or since.

100. See generally BIRD, supra note 76; ALAN BRINKLEY, LIBERALISM AND ITS DISCONTENTS 164-209 (1998); ThOMas Alan SCHWARTZ, AMERICA's Germany: JOHN J. MCCloy and THE FEDERAL REPUBLIC OF GERMANY (1991).

101. See Frederic S. NATHAN, Centurions in Public Service: Particularly as Presidents, SUPREME COURT JUSTICES \& CABINET MEMBERS 108-09 (2010) (describing the evolution of the pattern of young lawyers taking public service jobs and then returning to New York).

102. See Robert F. Kennedy, N.U.S.A.S. "Day of Affirmation" Speech at the University of Cape Town, South Africa (June 6, 1966), http:/www.rfksafilm.org/html/speeches/unicape.php (quoting the Chinese curse "may he live in interesting times").

103. It goes without saying that the three lawyers I've selected as examples for this Article are far from the only New York lawyers born during this window who also combined distinguished public careers spanning the two world wars with longstanding ties to New York legal practice. Among the most obvious others are John Foster Dulles (born 1888) and Allen Dulles (born 1893), who both practiced law in New York at Sullivan \& Cromwell. See generally STEPHEN KInZER, THE BRotHERS: JOHN Foster DulLES, ALLEN DULLES, AND THEIR SECRET WORLD WAR (2013) (chronicling the lives of Dulles brothers). 


\section{The FALL OF LAWYERLy PRUDENCE IN INTERNATIONAL STRATEGY}

One can see some continuing, partly second-hand echoes of this rare experience in the next generation ${ }^{104}$ of lawyers who learned at the feet of the "double world war" generation. Consequently, the influence continued with people born during the first decade or two of the 20th century. ${ }^{105}$ But the influence of the particular type of double

104. The reality, and significance, of "generations" in any particular context is of course always a longcontested issue. A number of scholars have discussed the concept and significance of generations in the history of American foreign policy. See generally ARTHUR M. SCHLESINGER, PATHS TO THE PRESENT (1964); Frank L. Klingberg, The Historical Alternation of Moods in American Foreign Policy, 4 WORLD POL. 239, 239-373 (1952); Frank H. Denton \& Warren Phillips, Some Patterns in the History of Violence, $12 \mathrm{~J}$. CONFLICT RESOL. 182, 182-95 (1968); Samuel P. Huntington, Paradigms of American Politics: Beyond the One, the Two, and the Many, 89 POL. SCI. Q. 1, 1-26 (1974); YUEN FOONG KHONG, ANALOGIES AT WAR: KOREA, MUNICH, DIEN BIEN PHU, AND THE VIETNAM DECISIONS OF 1965 (1992); Jack S. Levy, Learning and Foreign Policy: Sweeping a Conceptual Minefield, 48 INT'L ORG. 279 (1994). But I want to suggest that a resolution of these academic debates is unnecessary for the argument of this Article, which is not chiefly concerned with the lessons different generations (however defined) may or may not have drawn from different experiences. My focus here is instead on trying to tease out a common sensibility possessed by a select group of individuals who (1) shared a common formative professional training and practice as New York corporate lawyers during a period roughly bounded by the first four decades of the 20th century and (2) were directly involved as soldiers and officials in both of the two world wars-thus allowing them, in effect, to serve as members of something like a single, unusually extended, generation. While the juxtaposition of these two pivotal sets of experiences is my own, I am greatly indebted to the work of legal historian Robert W. Gordon for my understanding of the distinctive professional ethos of elite New York legal practice of the late 19 th and early 20 th centuries, including the emphasis on the ideal of the "citizen lawyer." To take just one example from his many articles over the past three decades touching on this broad subject, in his 1988 article, Gordon describes as arguably "a true Golden Age compared to the present" the period 1900-1975- which roughly coincides with the combined period of peak professional activity of Stimson, Root, $\mathrm{J}_{\mathrm{r}}$. and McCloy taken together. Robert W. Gordon, The Independence of Lawyers, 68 B.U.L. REV. 1, 60 (1988). For other relevant works by Robert W. Gordon, see generally Robert W. Gordon, "The Ideal and the Actual in the Law": Fantasies and Practices of New York City Lawyers, 1870-1910, in THE NEW HIGH PRIESTS: LAWYERS IN POST-CIVIL WAR AMERICA 51 (Gerard W. Gewalt ed., 1984); Robert Gordon, The American Legal Profession, 1870-2000, in 3 THE CAMBRIDGE HISTORY OF LAW IN AMERICA: THE TWENTIETH CENTURY AND AFTER (1920-) 73 (2008); Robert W. Gordon, The Citizen Lawyer: A Brief History of a Myth with Some Basis in Reality, 50 WM. \& MARY L. REV. 1169 (2009).

105. An obvious example of a group to which this applies are lawyers who might be called the "children of Root Clark"-lawyers such as Fowler Hamilton (b. 1911) and George Ball (b. 1909, another of the founding partners of the Cleary Gottlieb law firm that descended from the Root Clark firm), who either worked directly with Root, Jr. or Clark or as the close colleagues of others who had (such as the other founding partners of Cleary Gottlieb), and thus picked up through a kind of osmosis the lawyerly habits of mind not only of Root and Clark and their partners, but also of the lawyers that the Root Clark lawyers themselves looked up to such as Stimson and Elihu Root, Sr. - as well as the habit of thinking that they were quite capable of contributing valuable broader strategic insights and management capabilities to the world of U.S. international strategy. See GOTTLIEB, supra note 45 (describing Fowler Hamilton's association with the Root Clark firm); see also GEORGE W. BALL, THE PAST HAS ANOTHER PATTERN: MEMOIRS 101 (1982) (describing Ball's decision with Fowler Hamilton and Hugh Cox in 1945 to join with the four partners leaving the Root Clark firm to form a new, conjoined firm known initially in New York as Cleary, Gottlieb, Friendly \& Cox, and from 1950, as Cleary, Gottlieb, Friendly \& Hamilton, and in Washington as Cleary, Gottlieb, Friendly \& Ball). In an exceptional case or two this transmission mechanism might even extend to a New York lawyer born in the second decade of the 20th century, such as Cyrus Vance (b. 1917), who regarded the eminent New York lawyer John W. Davis (b. 1873) of the New York firm Davis, Polk \& Wardwell as a father figure and early on worked at the New York firm of Simpson, Thacher \& Bartlett. See DAVID S. MCLELLAN, CYRUS VANCE 1-5 (1985) (describing Vance's close relationship with his uncle John W. Davis and summarizing his tenure at Simpson Thacher \& Bartlett prior to his public service in the Defense 
world war-learned and war-tested lawyerly prudence described here had significantly faded by the time we got to the generation whose direct strategic experience was oriented solely around WWII, rather than both world wars.

I want to avoid psychoanalyzing these figures, so I leave my comment on this "WWII only" generation at this: Perhaps it was possible for someone to have one "good" world war-one in which things seemed to go more or less the right way (eventually). But from my study of the experience of the "double world war" generation (consistent with my own lesser experience), it seems exponentially harder to have had two "good" world wars ${ }^{106}$ (recall the sentiment attributed to Elihu Root, Jr. at the end of WWII: "[I]t was impossible to determine in advance what man's ingenuity might accomplish when faced with desperate necessity." ${ }^{107}$ ). Instead, that uniquely intensive degree of experience seemed to have almost inevitably underscored the difficulty of fully predicting or controlling the consequences of large-scale international actions, ${ }^{108}$ and to have underscored the power of not only intended but also unintended consequences. ${ }^{109}$

In any case, by the 1960 s the social factors that had supported a special role for lawyerly prudence in U.S. foreign and national security policy and international strategy had undergone some significant changes. First was the rise of new disciplinary competitors in the policy elite with their own claims to special expertise on international matters, most notably economists and political scientists. ${ }^{10}$ Second,

Department during the Kennedy and Johnson administrations and as Secretary of State during the Carter administration). After that, however, the transmission seems to grow unavoidably faint. While many lawyers born after WWI obviously still established impressive legal practices in a proliferating number of U.S. metropolitan centers apart from New York - including Chicago, Dallas, Los Angeles, and eventually most of the nation's biggest cities - by the time they came to maturity there appears to have been less of an accepted pattern of back-and-forth movement to Washington. Infra note 119. Consequently, it became more common for ambitious lawyers either to move to Washington and not return or to simply resist the temptation of Washington in the first place.

106. Relevant to this theme generally is an observation by the theologian and nationally influential realist foreign policy commentator during the early post-WWII period Reinhold Niebuhr, who noted in a 1956 preface to a book of his originally published in 1929 :

As the self-revelations of a young parson [these notes] express the then typical notions of liberal Protestantism before the whole liberal world view was challenged by world events. Of course they were written after the first world war. But that war did not essentially challenge the liberal culture of America. It required a depression and another world war to corrode an optimism in America which was lost in Europe after the first world war.

\section{REINHOLD NIEBUHR, LEAVES FROM THE NOTEBOOK OF A TAMED CYNIC 8 (1956).}

107. PERERA, supra note 71 , at 79 .

108. It is irresistible to quote on this proposition the unimpeachable (albeit non-lawyer) Dwight D. Eisenhower, who famously said in 1946: "I hate war as only a soldier who has lived it can, only as one who has seen its brutality, its futility, its stupidity." Dwight D. Eisenhower, Address at the Canadian Club (Jan. 10, 1946).

109. The definitive description of the phenomenon of unintended consequences was given by Robert K. Merton. Robert K. Merton, The Unanticipated Consequences of Purposive Social Action, 1 AM. SOC. REV. 894, 894-904 (1936); see also The Paradox of Complexity, supra note 2, at 32, 33. The importance of recognizing unintended consequences of public policies remains a common theme. See, e.g., AARON WILDAVSKY, SPEAKING TRUTH TO POWER 47 (1987) (“[S]ociety's capacity for measuring results has outstripped its ability to cause consequences. We know that programs have failed but we have been unable to bring about the changes in behavior that would have labeled them successful.").

110. See generally YVES DEZALAY \& BRYANT G. GARTH, THE INTERNATIONALIZATION OF PALACE WARS: LAWYERS, ECONOMISTS, AND THE CONTEST TO TRANSFORM LATIN AMERICAN STATES (2002). 
Washington developed as an economic and cultural ecosystem in its own right. ${ }^{111}$ While Washington did not necessarily become less dependent on importing talented lawyers (and other professionals) from New York and other major cities, the growth of Washington's economy made it less necessary and less attractive for those imported professionals to return to where they came from after investing time and effort learning how government and Washington worked. ${ }^{112}$ In short, what had been a "twoway ticket" between New York and Washington, D.C. for our exemplary New York lawyer-statesman into the 1960 s now increasingly became a "one-way ticket."

Third, partly in response to the previous two changes, New York and other nonWashington lawyers tactically began to cede the territory of international policy and strategic matters to Washington, and instead increasingly focused their efforts on issues with a more obvious legal dimension. ${ }^{113}$ In their chapter Law, Lawyers, and Empire, ${ }^{114}$ Garth and Dezelay describe the process by which New York lawyers interested in international policy gradually shifted their emphasis from strategic questions to fields such as international human rights law and international commercial arbitration that could be more easily protected as the inherent preserve of lawyers and kept to a greater extent in New York. ${ }^{115}$ Fourth, the pace required of lawyers working for rich and demanding financial sector clients on Wall Street increased to such a degree that it required a virtually total commitment by ambitious lawyers, leaving New York lawyers working in big firms in the 1970s with little time to think about international strategy and straddle the Northeast corridor between New York and Washington, except on client business. ${ }^{116}$ Finally, in part to compensate for the loss of time that could be have been used for other things, the Wall Street legal sector became by the 1980 s so remunerative that the idea of leaving it for a lowerpaying government job (and uncertain prospects if one later wanted to return) became increasingly unpopular. ${ }^{17}$ The result of all this was that by the 1980 s the tradition of lawyerly prudence in international strategy had largely faded away. John McCloy died in $1989 .{ }^{118}$

111. See generally MEG GREENFIELD, WASHINGTON (2001).

112. Robert $G$. Kaiser provides a rich history of the rise of the lobbyist sector in Washington since WWII and particularly since the 1970s. See generally ROBERT G. KAISER, SO DAMN MUCH MONEY: THE TRIUMPH OF LOBBYING AND THE CORROSION OF AMERICAN GOVERNMENT (2009) (explaining how so many lawyers who were more traditional lawyers in their original city and perhaps originally came to Washington in order to serve in government ended up choosing to stay in Washington and join the lucrative and growing legal/lobbying sector).

113. DEZALAY \& GARTH, Law, Lawyers and Empire, supra note 29, at 740-57.

114. Id.

115. Id. at 44-51.

116. NATHAN, supra note 101 , at 114-15.

117. Contrast this state of affairs with the older and more flexible expectations of legal employers and their bank clients described by Stimson in his 1948 autobiography. Id. at 119-21 ("During my various excursions into public life I always felt that I remained a lawyer with a law firm waiting as a home behind me, to which I could return on the completion of my public task. . . This feeling gave me a confidence in the performance of my public duties which was an inestimable encouragement.").

118. A kind of testament to McCloy and the end of the old tradition can be found in Alan Brinkley's 1983 profile of McCloy, which concluded by recounting "a story making the rounds at cocktail parties in Washington and New York about an episode in the 1980 presidential campaign." Alan Brinkley, Minister Without Portfolio, HARPER's, Feb. 1983, at 46. As Brinkley described it, 


\section{THE FUTURE OF PRUDENCE IN INTERNATIONAL STRATEGY: FROM LAWYERLY TO POST-LAWYERLY}

Let me close by returning to the specific context for the question of the contemporary utility of prudence in international strategy presented by this symposium: How we should best learn from our relevant recent experiences with interventions in Iraq, Afghanistan, and elsewhere in the region in deciding a current strategy for responding to the challenge of ISIS, while giving due consideration for the future. The first part of my argument has been an indirect one: That the most effective way for us to meet the ISIS challenge-or really any strategic-level international problem, private as well as public, and economic as well as political or military -is to identify people with the background and qualities to approach strategic challenges in a manner comparable to that which the New York lawyer-statesmen we've discussed might have used-namely, in a lawyerly prudent matter that, as in Titian's painting, learns from the experience of the past, and acts prudently in the present, to avoid spoiling tomorrow.

However, the other part of my historical argument has been that for overdetermined reasons, the tradition of "lawyerly prudence" in international strategy, practiced as I've described it here, is now, in essence, a dead letter.

Consequently, the final questions we are left with are: (1) Whether any or all of the elements of lawyerly prudence are still valuable, and (2) if so, can they exist and be cultivated in a broader group of citizen-statespeople who have acquired relevant, comparably intense experience?

To answer this, recall the fundamental qualities of lawyerly prudence sketched out near the beginning of this Article and illustrated through the accounts of our three New York lawyer-statesmen: (1) Experience with the complexity that follows from national and international scale activity, in matters public and private; (2) a heightened awareness of the uncertainty inherent in complex (especially international) undertakings, and from that, a humble recognition that the consequences of actions cannot always be predicted or controlled; ${ }^{119}(3)$ appreciation of at least recent history as something that necessarily influences, and constrains the forms of, political change; ${ }^{120}$ and (4) a substantial store of direct experience of strategically consequential events.

John Anderson - in the heat of the primaries, when it appeared he might have a chance-called John McCloy (as political figures have been doing for forty years) and asked for some advice. $\mathrm{He}$ wanted the name of someone in the Stimson-Acheson-McCloy tradition, someone experienced in the corporate establishment and yet wise in international affairs, a Wall Street lawyer who might make a good secretary of state. McCloy hardly paused to think before answer: "You won't find one. Those lawyers don't exist anymore. They're all too busy making money."

Id.

119. The great international relations scholar Hans Morgenthau taught us that international relations requires no less than "cosmic humility," because "[t]o know that states are subject to the moral law is one thing; to pretend to know what is morally required of states in a particular situation is quite another." Hans J. Morgenthau, Another "Great Debate": The National Interest of the United States, 46 AM. POL. SCI. REV. 961, 983-84 (1952); see also David Wolitz, Indeterminacy, Value Pluralism, and Tragic Cases, 62 BuFF. L. REV. 529, 587 (2014) (discussing the ways uncertainty and indeterminacy leads to tragic choices where a decision maker must decide, even while knowing that he or she lacks full knowledge of the consequences of his or decision).

120. Note that a lawyerly appreciation of at least the recent past (because the past is one of the constraints 
In fact, this last element was the spur to my first insight that eventually led to this Article: When it occurred to me that if direct experience of strategically consequential events is a necessary condition for prudence, a significant number of our contemporaries today have already accumulated quite a significant store of strategically significant experience since September 2001, and done so during an even more compressed period than the double war generation -15 years versus 30 . To put it differently, the contingent historical fact that we were born when we were and thus ended up in a position to experience the big strategic events of the last 15 years at least gives us a shot at recreating a version of the old lawyerly prudence. While we have not had two world wars, we have had two fairly large-scale (by contemporary standards) regional interventions, as well as many smaller interventions, and a wide range of ongoing war-like activities (and this is to say nothing of the potentially even more strategically consequential international financial crises since 2008). My original question was: Can we take advantage of this opportunity? Is it possible for a critical mass of people today to also embrace the other elements of lawyerly prudence and then pull the pieces together into a coherent and self-conscious sensibility that might serve (with appropriate updates as necessary) as a kind of new (or post-) lawyerly prudence for our time?

So far, the record has not been particularly encouraging. As a final personal data point, eight years ago I gave a talk at New York Law School based on my experiences to that point in Iraq, on what I thought were the mistakes and lessons (on the civilian side) of the Iraq intervention. ${ }^{121}$ Nonetheless, just a couple of years later, I found myself in Afghanistan trying to undo some strategy mistakes that sometimes seemed eerily similar. ${ }^{122}$

Nonetheless, I think it is possible to leave us in at least a potentially optimistic place about the future of a "post-lawyerly prudence." While it is true that the group that exemplified these distinctive qualities in the past-namely lawyers who were products of the distinctive professional training, legal practice, and war-time experiences described here - have become, since roughly the last third or quarter of the 20th century, unable to bear the same responsibility for exemplifying the qualities that they did 100,75 , or even 50 years ago, it is also true that the challenging

on the future) is distinct from a true historian's detailed knowledge of history for its own sake. As such, the level of knowledge of the past necessary for lawyerly prudence is a much less demanding standard than has sometimes been suggested by eminent historians. See generally ERNEST R. MAY, "LESSONS" OF THE PAST: THE USE AND MISUSE OF History IN AMERICAN FOREIGN POLICY (1973); RICHARD E. NEUSTADT \& ERNEST R. MAY, THINKING IN TIME: THE USES OF HISTORY FOR DECISION MAKERS (1986). May and Neustadt offer many examples of good and bad uses of history in foreign policy and make many useful suggestions about how to avoid common pitfalls. More recently, Allison and Ferguson take up May and Neustadt's argument for the value of "historian's history" being part of the policymaking process and propose to operationalize it by calling for a group of actual historians to be made a part of the White House staff. Graham Allison \& Niall Ferguson, Why the U.S. President Needs a Council of Historians, ATLANTIC (Sept. 2016), https://www.theatlantic.com/magazine/archive/2016/09/dont-know-much-about-history/ 492746/ [https://perma.cc/XYL5-9T4L]. This is a thought-provoking idea, but I mention it only to make clear that the understanding of the past I have discussed here is quite explicitly the less-demanding level of understanding of a well-educated lawyer rather than that of a trained historian. While knowledge of the past has inherent value and almost always has some use, to be lawyerly prudent one only has to know enough about the past to have some sensitivity to the kinds of pitfalls that might jeopardizing the future.

121. Jeremiah S. Pam, C.V. Starr Lecture: State-building and the Interplay Between U.S. and Local Institutions: Lessons from Iraq, Center for International Law, New York Law School (Nov. 5, 2008).

122. See generally The Rise and Fall, supra note 2. 
international events of the last 15 years have provided the opportunity for the creation of new groups of citizen-statespeople whose international strategic judgment, like that of their lawyer-statesmen predecessors, has been forged in part by direct experience in multiple international strategic crises. And the direct experience of these crises has given these select citizen-statespeople the raw material with which it might yet be possible to self-consciously formulate a new sensibility of prudence: One that begins with the key components of the old lawyerly prudence --experience with complexity; awareness of inherent uncertainty and the related imperative of humility; appreciation of at least the recent past; and last but not least, a constantly-interrogated store of the hard-earned lessons of experiences over the last 15 years - and then adds to these any new components called for by the particularities of our own era. If we think what I've called lawyerly prudence was useful in the past, perhaps the least that can be said is that post-lawyerly prudence is worth a try in the present. 


\section{ANNEX}

Titian and Workshop, An Allegory of Prudence (1565), http:/www.nationalgallery.org.uk/paintings/titian-an-allegory-of-prudence [https//perma.cc/TLZ2-RL2P].

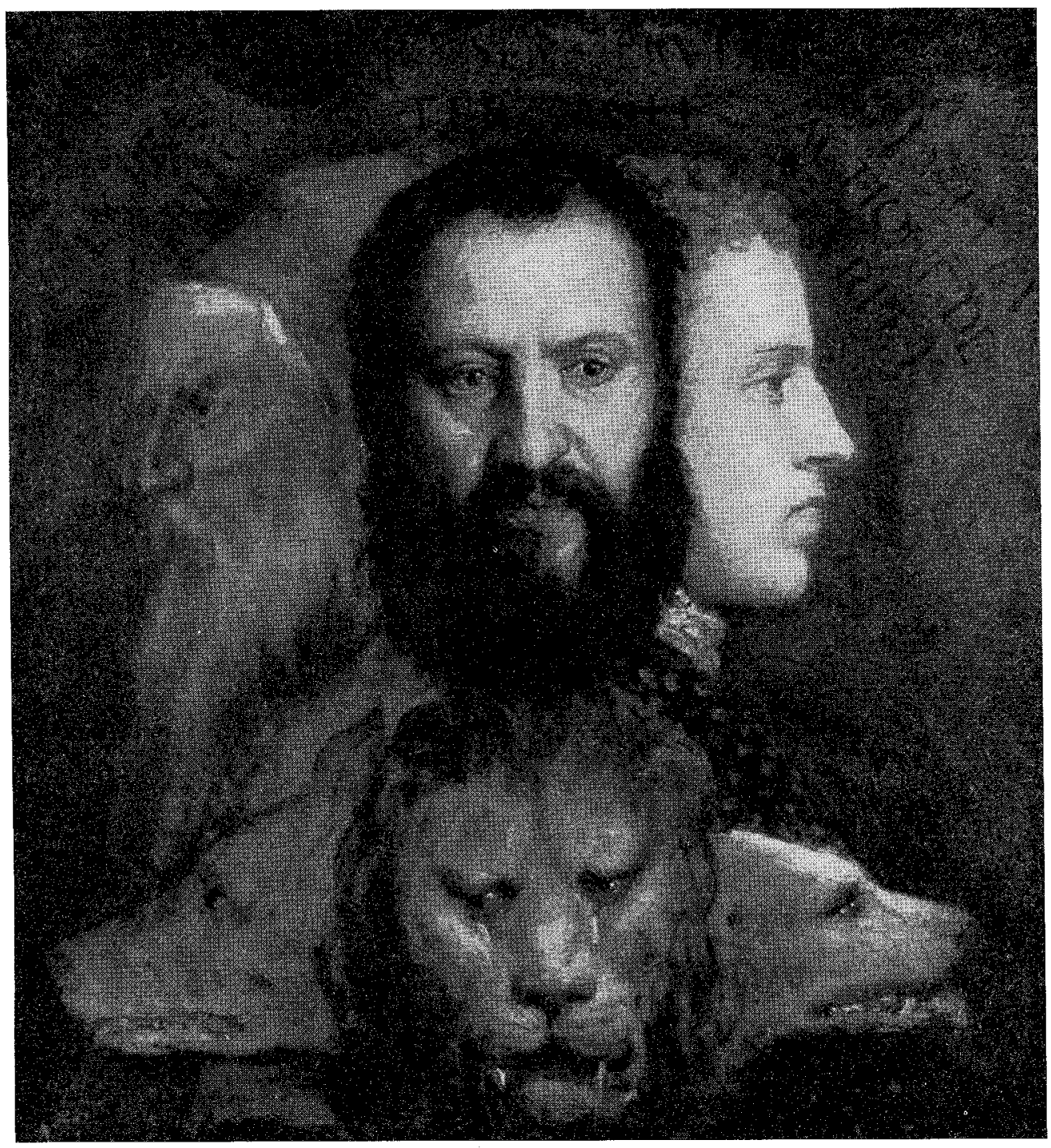


